FabrícIo da Silva Costa ${ }^{1}$

PADMA MURTH ${ }^{2}$

ROSEMARY KEOGH ${ }^{2}$

NICOLE WOODROW ${ }^{3}$

Revisão

Keywords

Pre-eclampsia/diagnosis

Risk factors

Uterine artery/ultrasonography

Biological biomarkers

Palavras-chave

Pré-eclâmpsia/diagnóstico

Fatores de risco

Artéria uterina/ultrassonografia Marcadores biológicos

\title{
Early screening for preeclampsia
}

\author{
Rastreamento precoce da pré-eclampsia
}

\section{Abstract}

Preeclampsia, which affects about 3 to $5 \%$ of pregnant women, is the most frequent medical complication in pregnancy and the most important cause of maternal and perinatal morbidity and mortality. During the past three decades, numerous clinical, biophysical, and biochemical screening tests have been proposed for the early detection of preeclampsia. Literature shows large discrepancies in the sensitivity and predictive value of several of these tests. No single screening test used for preeclampsia prediction has gained widespread acceptance into clinical practice. Instead, its value seems to be in increasing the predictive value of panels of tests, which include other clinical measurements. The aim of this review was to examine the combination of maternal risk factors, mean arterial blood pressure, and uterine artery Doppler, together with biomarkers in the preeclampsia prediction.

\section{Resumo}

A pré-eclâmpsia, que afeta cerca de 3 a $5 \%$ das mulheres grávidas, é a mais frequente complicação médica durante a gestação e a mais importante causa de morbidade e mortalidade maternal e perinatal. Durante as últimas três décadas, numerosos testes de rastreamento clínicos, biofísicos e bioquímicos foram propostos para a detecção precoce da pré-eclâmpsia. A literatura mostra grandes discrepâncias na sensibilidade e no valor preditivo de muitos desses testes. Nenhum teste de rastreamento isolado usado para a predição da pré-eclâmpsia tem ganhado ampla aceitação na prática clínica. Ao contrário, parece que o valor preditivo aumenta com a inclusão de um painel de testes, os quais incluem outros parâmetros clínicos. $\bigcirc$ objetivo desta revisão foi examinar a combinação dos fatores de risco maternos, a pressão arterial média, o Doppler das artérias uterinas com os marcadores séricos, na predição da pré-eclâmpsia.

Correspondência:

Fabricio da Silva Costa Royal Women's Hospital Pregnancy Research Centre

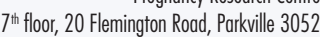
Melbounne - Australia

Recebido $01 / 09 / 2011$
' Consultant at the Department of Perinatal Medicine and Pauline Gandel Imaging Centre, Royal Women's Hospital and Clinical Senior Lecturer, University of Melbourne Department of Obstetrics and Gynecology; Senior Research Fellow at the Department of Perinatal Medicine Pregnancy Research Centre and University of Melbourne Department of Obstetrics and Gynaecology, Royal Women's Hospital, Parkville - Victoria, Australia.

${ }^{2}$ Senior Research Fellow at the Department of Perinatal Medicine Pregnancy Research Centre and University of Melbourne Department of Obstetrics and Gynaecology, Royal Women's Hospital, Parkville - Victoria, Australia.

${ }^{3}$ Clinical Director of Ultrasound Services, Pauline Gandel Imaging Centre, Royal Women's Hospital, Parkville - Victoria, Australia. 
Introduction

Preeclampsia (PE) is one of the hypertensive pregnancy disorders, which affects from 3 to $5 \%$ of pregnant women. It is the most important cause of maternal morbidity and perinatal mortality. On a global scale, PE is responsible for approximately 50,000 maternal deaths annually ${ }^{1}$. In addition, PE frequently coexists with intrauterine growth restriction (IUGR, also called fetal growth restriction), placental abruption, and the need for iatrogenic preterm delivery, which are additional major causes of adverse outcomes ${ }^{2}$.

$\mathrm{PE}$ is developed after 20 weeks of gestation and is characterized by hypertension and proteinuria ${ }^{3}$. However, the pathophysiology of PE remains incompletely elucidated. Circulating factors are postulated to be produced by the placenta as a result of oxidative stress. This may cause excessive systemic inflammatory response ${ }^{4}$ and generalized maternal endothelial dysfunction, contributing to the maternal clinical features of $\mathrm{PE}^{4-6}$. Shallow placentation is associated with abnormal invasion of cytotrophoblasts, leading to incomplete remodeling of maternal uterine spiral arterioles, which supply blood to the developing placenta $^{7,8}$. The ensuing hypoxic stress in the placenta is associated with the release of endothelial damaging factors into the maternal circulation ${ }^{5,9}$.

PE can be classified into early- and late-onset, and it is widely accepted that these subtypes of PE represent different forms of the disease. Early-onset PE is commonly associated with IUGR, abnormal uterine, and umbilical artery Doppler waveforms, and adverse maternal as well as neonatal outcomes ${ }^{1,3,5,10,11}$. In contrast, late-onset PE is mostly associated with mild maternal disease and low rate of fetal involvement; the perinatal outcomes are usually favorable $e^{3,5,10}$.

A major retrospective study showed that current standards of prenatal care are not effective for identifying relatively common obstetric problems, such as $\mathrm{PE}$ in lowrisk populations ${ }^{12}$. Furthermore, a randomized multicenter study concluded that regular obstetric consultations conducted in a tertiary centre do not improve the antenatal detection of PE, compared with primary care $^{13}$.

During the past three decades, numerous clinical, biophysical, and biochemical tests have been proposed for early detection of PE. These tests can require either noninvasive or invasive procedures, or a combination of both, to obtain the sample or measurement. Some tests have been studied extensively, whilst others are still at the level of laboratory research or under pre-clinical trials. Literature shows large discrepancies in the sensitivity and predictive value of several of these tests. It is a contributing factor to the lack of widespread adoption of these tests into clinical practice.
Early detection of PE would allow for planning the appropriate monitoring and for clinical management, following the early identification of disease complications. Although trials of prophylactic intervention for PE from mid-gestation have not been efficacious, it has been suggested that a very early prediction of PE in gestation may make early prophylactic strategies more effective ${ }^{2}$.

Reliable antenatal identification of PE is crucial to cost-effective allocation of monitoring resources and to use possible preventative treatment ${ }^{14}$ with the hope of improving maternal and perinatal outcomes. The literature is difficult to interpret and this prevents the implementation of good clinical management practices for the several clinical scenarios of PE. The variation in research design for determining the test accuracy for the prediction of $\mathrm{PE}$, the scatter of this research across many databases and languages, and the dearth of clear, collated up-to-date summaries of the relevant literature, contribute to the uncertainty about the best screening and monitoring strategies ${ }^{15}$. A logical approach to obtain an ideal predictive test for PE is to utilize a combination of several potential predictors, which reflect different aspects of the disease.

\section{Maternal factors}

Maternal history including ethnic origin, parity, body mass index (BMI), and personal or family history of $\mathrm{PE}$ are well-known risk factors for $\mathrm{PE}^{16}$. Among women considered as high-risk, approximately $25 \%$ will develop $\mathrm{PE}$ compared with $5 \%$ in the general population ${ }^{17}$.

The National Institute of Clinical Excellence (NICE) in the United Kingdom (UK) recommends a screening strategy based on maternal history and on other risk factors. Unfortunately, it categorizes more than $60 \%$ of pregnant women as high-risk and predicts less than $30 \%$ of those destined to develop PE, at a false-positive rate of $10 \%{ }^{2}$. Poon et al. ${ }^{18}$ showed in a study on a large population that certain risk factors significantly predicted early- and late-onset $\mathrm{PE}$ with different detection rates of 37 and 29\%, respectively, for a 5\% false-positive rate. Different subsets of factors were better at predicting early-onset PE (previous history of PE, black ethnicity, pre-existing hypertension, and previous use of ovulation inductors) than the late one (maternal or family history of PE, black ethnicity, BMI, and maternal age). Pre-existing maternal subclinical endothelial dysfunction is likely to make a woman more vulnerable to poor placentation and more sensitive to the consequences of placental dysfunction ${ }^{19}$.

The SCOPE Group developed a predictive model for $\mathrm{PE}$ based on clinical risk factors for nulliparous women. 
Using that approach, $9 \%$ of nulliparous women would be referred to a specialist care, of whom $21 \%$ would develop PE. The authors concluded that the ability to predict PE in healthy nulliparous women using clinical phenotype is modest and requires external validation in other populations ${ }^{20}$. Unfortunately, screening for PE using maternal history alone is an unreliable method. This is especially true in primigravid women, the very population where the incidence of PE is the highest. Since the development of PE is thought to include abnormal placentation and its vascular supply, it is logical to follow the evaluation of uterine artery blood flow resistance. Some recent publications showed that a more effective approach is the one that combines maternal history with measurement of blood pressure, uterine artery Doppler, and serum biomarkers ${ }^{16,18}$.

\section{Mean arterial blood pressure}

Very small changes in the blood pressure were found to be a marker of the risk of developing $\mathrm{PE}^{19}$. Women who subsequently develop PE have higher systolic blood pressure and mean arterial blood pressure (MAP) readings before the onset of clinical disease ${ }^{7}-$ where MAP is twice the diastolic plus the systolic blood pressure, divided by three.

Changes in blood pressure are most likely a proxy for increased maternal vascular susceptibility to PE, or they are a marker for underlying and undiagnosed hypertension ${ }^{21}$. Accurate measurement of blood pressure using a validated automatic monitor is particularly important when attempting to identify early signs of PE. As a means of prediction, the MAP, whether measured in the first or second trimester, is suggested to be a better predictor than the systolic and diastolic blood pressure or an increase in blood pressure ${ }^{22}$. Cnossen et al. ${ }^{22}$ conducted a systematic review and they showed that the MAP was a better predictor for PE than an increase in either the systolic or diastolic blood pressure. Second trimester MAP of $90 \mathrm{mmHg}$ or above showed a positive likelihood ratio of $3.5(95 \% \mathrm{CI}=2-5)$ and a negative likelihood ratio of 0.46 (95\% CI=0.16-0.75). In a prospective cohort study, the utility of MAP was assessed in 104 patients, who subsequently developed $\mathrm{PE}$, and 4,418 patients unaffected by hypertensive disease and with normal birth-weight infants. Combining MAP with prior risk factors, the observed detection rate PE was $62 \%{ }^{23}$.

Maternal MAP is an easy, cost-effective, and noninvasive test that can be performed in all women at their first routine antenatal visit. MAP can readily be combined with uterine artery Doppler studies and biomarkers.

\section{Ultrasound}

\section{Uterine artery Doppler}

Poor placentation with deficient remodeling of the spiral arteries has been associated with subsequent development of the early-onset forms of PE, IUGR, and other associated complications ${ }^{7,8,24}$. In these abnormal pregnancies, the uteroplacental circulation remains in a state of high resistance, which can be measured noninvasively by uterine artery Doppler ultrasound ${ }^{25}$. The impedance is increased in early PE and IUGR and predates the onset of the clinical symptoms by several weeks ${ }^{19}$.

A number of studies examined the effectiveness of uterine artery Doppler in predicting the complications associated with impaired placentation. Most studies used uterine artery Doppler measured in the second trimester, but there is an increasing number of studies showing the effectiveness of first trimester uterine Doppler measurements in the prediction of PE and IUGR ${ }^{26}$. Early reports used subjective qualitative assessment evaluating the presence of a diastolic notch. However, in the last ten years, the use of continuous variables has achieved widespread acceptance as they provide more objective measurements to quantify the vascular impedance. Specifically, the mean pulsatility index (PI) has been studied as an objective measurement, and normal ranges from 11 to 41 weeks have been published ${ }^{27}$.

A feature of uterine artery screening is that the detection rates are better for the pre-term and/or early form of $\mathrm{PE}$ than for severe or mild PE. Second-trimester uterine artery Doppler studies showed detection rates of 70 to $80 \%$ for pre-term PE, while the detection rates are 30 to $40 \%$ for PE at any gestational age, with false-positive rates between 5 and $7 \%{ }^{28}$. In Brazil, Costa et al. ${ }^{29}$, when studying second trimester uterine artery Doppler in a low-risk population, showed high sensitivity for prediction of $\mathrm{PE}$, however with only a $29 \%$ positive predictive value.

First trimester screening shows a similar trend, although overall detection rates are lower than second trimester screening. Around $40 \%$ of women who subsequently develop PE requiring delivery at less than 37 weeks gestation will be correctly classified, with a falsepositive rate of $5 \%{ }^{23,30}$.

The use of uterine artery Doppler as a screening tool for PE and other pregnancy complications, such as IUGR, remains controversial. Criticism has tended to focus on the low-positive predictive values for term disease reported in clinical trials in low-risk populations. However, when attention is focused on early-onset PE, which causes the highest burden of perinatal morbidity and mortality, the evaluation of uterine artery Doppler performance suggests it is an important predictor. The search continues for a combination of tests that could work better than, or in 
association with, uterine artery Doppler to maintain the high sensitivity, but that improve specificity ${ }^{31}$.

\section{Placental volume and 3D power Doppler}

Placental maldevelopment plays a pivotal role in the pathogenesis of PE. Three-dimensional (3D) ultrasound has the potential to provide improved visualization of the fetal anatomy compared with conventional 2D ultrasound imaging. Consequently, the introduction of $3 \mathrm{D}$ ultrasound would facilitate the novel assessment of the placenta, such as surface-rendering imaging and volume measurement. With the recent advances in 3D Power Doppler ultrasound, as well as quantitative 3D Power Doppler histogram analysis, quantitative and qualitative assessments of the vascularization and blood flow of the placenta have become feasible $^{32}$. 3D sonographic placental volume measurements using multiplanar Virtual Organ Computer-aid Analysis (VOCAL) and Extended Imaging VOCAL (XI VOCAL) have been reported. Studies on the prediction of adverse pregnancy outcomes, including IUGR and PE using placental volume measurement in the first trimester of pregnancy, have shown inconsistent results ${ }^{32}$.

3D power Doppler ultrasound can depict internal placental vessel characteristics such as density of vessels, branching, caliber changes, and tortuosity ${ }^{32}$. Several small studies have suggested that parameters derived from 3D Power Doppler evaluation of the placenta in the first trimester can predict adverse pregnancy outcomes, including PE and IUGR. While the findings from these studies are promising, the methodologies used and the definitions of abnormal indices have varied ${ }^{33}$. In a recent prospective nonintervention study of 277 women at 10 to 13 weeks, the 24 who later presented PE had significantly reduced indices of vascularization and blood flow $^{34}$. It remains to be seen if first trimester placental volume using 3D Power Doppler is an independent marker of PE compared with uterine artery Doppler PI.

\section{Biomarkers}

Biochemical markers of PE are circulating factors, the measurement of which could potentially be used in the diagnosis or prediction of PE. Some markers are products of trophoblast cells or of the adjacent decidua and they reflect placental dysfunction, which is an important aspect of the PE pathogenesis. Other biomarkers include inflammatory and metabolic markers arising from systemic responses of maternal systems to abnormal pregnancy. An increasing number of biomarkers in the maternal serum display altered concentrations during the first trimester of pregnancy ${ }^{35}$.

In this review, we described known biomarkers of PE based on their source. The first group of biomarkers are exclusively placental in origin, such as PP13. This group can be further subdivided into those that are expressed in the placental villous trophoblast or in the extravillous one. The second group are biomarkers exclusively of maternal origin like P-selectin. The third group of biomarkers is expressed by both maternal and fetal tissues, such as s-Flt and PIGF.

\section{Biomarkers from the placenta}

Pregnancy-associated placental protein A

Pregnancy-associated placental protein A (PAPP-A) is a large and highly glycosylated protein, which is produced by the developing trophoblast. PAPP-A modulates the activity of insulin-like growth factors by cleaving insulin-like growth factor binding proteins ${ }^{14}$. It is proposed to play a role in implantation ${ }^{15}$ and is used as a biomarker for Down's syndrome. In chromosomally normal pregnancies, there is evidence that low maternal serum PAPP-A is associated with an increased risk of subsequently developing PE. However, measurement of PAPP-A is not an effective stand alone screening tool for PE, because less than $20 \%$ of the affected cases present serum levels below the fifth centile ${ }^{28,36}$.

\section{Placental protein 13}

Placental protein 13 (PP13) is a member of the galectin family and is a $32-\mathrm{kDa}$ dimer protein, which is highly expressed in placenta, and specifically by the syncytiotrophoblast ${ }^{37-39}$. Several studies since 2004 have demonstrated that low concentrations of maternal serum PP13 in the first trimester predict $\mathrm{PE}^{40}$. Decreased mRNA for PP13 was also found in the first trimester ${ }^{41}$. In general, low PP13 in the first trimester seems to be a better predictor of early onset and severe PE than mild $\mathrm{PE}$ at term ${ }^{42}$.

\section{Cystatin C}

Maternal serum cystatin $C$ is another independent marker of $\mathrm{PE}^{2}$. It is an inhibitor of cysteine proteases, which are thought to play an important role in matrix degradation during normal trophoblast invasion. Cystatin $\mathrm{C}$ is reportedly increased in $\mathrm{PE}$ and it is also elevated in the first trimester in women destined to have PE, compared with those who will have a normal pregnancy ${ }^{43-45}$.

Fetal cells

Several independent studies have shown that PE is associated with an underlying placental lesion that 
facilitates the increased trafficking of fetal cells and the release of cell-free fetal $\mathrm{DNA}^{46}$. These studies have also shown that this placental defect occurs early in pregnancy, long before the onset of any clinical symptoms. Although advances have been made in the enrichment and isolation of fetal cells for analysis, a large multicentre analysis by the National Institutes of Health $(\mathrm{NIH})$ revealed that the sensitivity and specificity of cell-based methods were not satisfactory for aneuploidy detection ${ }^{47}$.

\section{Cell free fetal RNA and DNA}

Cell free fetal DNA (cffDNA) detection has been widely developed for use in noninvasive prenatal diagnosis. Most of the studies so far have demonstrated a significant difference in cffDNA levels in second trimester samples of patients that subsequently develop PE versus controls ${ }^{48,49}$. Studying placental and fetal gene expression by analyzing circulating fetal mRNA has recently shown promising results. Fetal RNA molecules in maternal plasma are associated with subcellular particles, including apoptotic bodies and syncytiotrophoblast microparticles ${ }^{50}$. Zhong et al..$^{51}$ and Purwosunu et al. ${ }^{52}$ have reported a parallel assessment of cffDNA and placental specific mRNA (i.e. corticotropin releasing hormone mRNA) in the second trimester, and they revealed that both were increased in early onset PE.

Inhibin $\mathrm{A}$ and activin $\mathrm{A}$

Inhibin $A$ and activin $A$ are glycoprotein hormones and members of the transforming growth factor (TGF)- $\beta$ family. The placenta is the primary source of these circulating proteins during pregnancy and their concentrations increase in the third trimester of uncomplicated pregnancies ${ }^{53}$. In a study, by Muttukrishna et al. ${ }^{54}$, increased serum inhibin $A$ and activin $A$ from second trimester was a poor predictor of $\mathrm{PE}$, with a predictive sensitivity from 16 to $59 \%$. However, early-onset disease was better predicted than the term-onset one. Also, Sibai et al. ${ }^{55}$ found that elevated second trimester serum inhibin A had a poor sensitivity in predicting PE in a high-risk group of women.

\section{Angiogenic factors}

Angiogenesis requires the complex interplay between the pro-angiogenic factors, vascular endothelial growth factor (VEGF) and placental growth factor (PIGF), with their cognate receptors VEGF receptor-1 (VEGFR-1, which is alternatively called FMS-like tyrosine kinase (flt)-1) and VEGFR-2. Interestingly, the placenta is a rich source of these factors, and several of these angiogenic factors have been shown to be key components in regulating trophoblast cell survival and function ${ }^{56}$. A cleaved form of soluble-Flt-1 has been reported to increase during third trimester in women who will develop PE within five weeks and at the time of the disease ${ }^{57}$. The mRNA encoding PlGF is produced in large amounts by villous and extravillous cytotrophoblasts and syncytiotrophoblast ${ }^{58}$. PE is associated with decreased serum PIGF in the early onset ${ }^{59}$. An additional angiogenic factor, soluble endoglin (sENG) was also observed to increase in PE. Thus, alterations in sFlt, PlGF and sENG are more pronounced in early onset $\mathrm{PE}$ compared with late onset $\mathrm{PE}^{60,61}$. A review of the literature for angiogenic markers reveals that they are mostly not specific for PE, since similar changes in angiogenic marker profiles are observed in cases of fetal growth restriction not associated with PE. This is particularly the case with sENG ${ }^{62}$.

\section{Molecules of maternal origin}

Pentraxin 3 (PTX3), an inflammatory molecule that belongs to PTX family such as $\mathrm{C}$-reactive protein, is expressed in response to inflammatory stimuli by endothelial cells, macrophages, and monocytes ${ }^{63}$. Recent studies suggest that PTX3 levels in early pregnancy are associated with the subsequent development of early onset PE, but not fetal growth restriction ${ }^{64,65}$. Poon et al. ${ }^{25}$ have recently reported that a combination of PTX3 and PlGF with other information, such as maternal health history, biophysical markers like mid-arterial pressure and Doppler ultrasound measurements, performs better for PE prediction in patients at 11 to 13 weeks pregnancy. Table 1 summarizes potential biomarkers in maternal blood for the prediction (first trimester and second trimester) or detection of PE.

\section{Combined screening}

As described, no single marker tested thus far has sufficient clinical value in the prediction of PE. Instead, the value of biomarkers seems to be in increasing the predictive value of panels of tests, which include other clinical measurements ${ }^{1}$. Different pathophysiological pathways are thought to converge in the common clinical syndrome of PE. This etiological complexity almost precludes the notion that a single test could not be successfully used to predict $\mathrm{PE}^{27}$. The search continues to find a combination of tests that will work better than, or in association with, uterine artery Doppler to maintain the high sensitivity, but to improve specificity ${ }^{31}$.

Numerous studies, using the combined screening approach, have been published in the last decade, 
Table 1. Summary of potential biomarkers for the prediction or detection of PE in maternal peripheral blood (adapted from Grill et al. $\left({ }^{42}\right.$ )

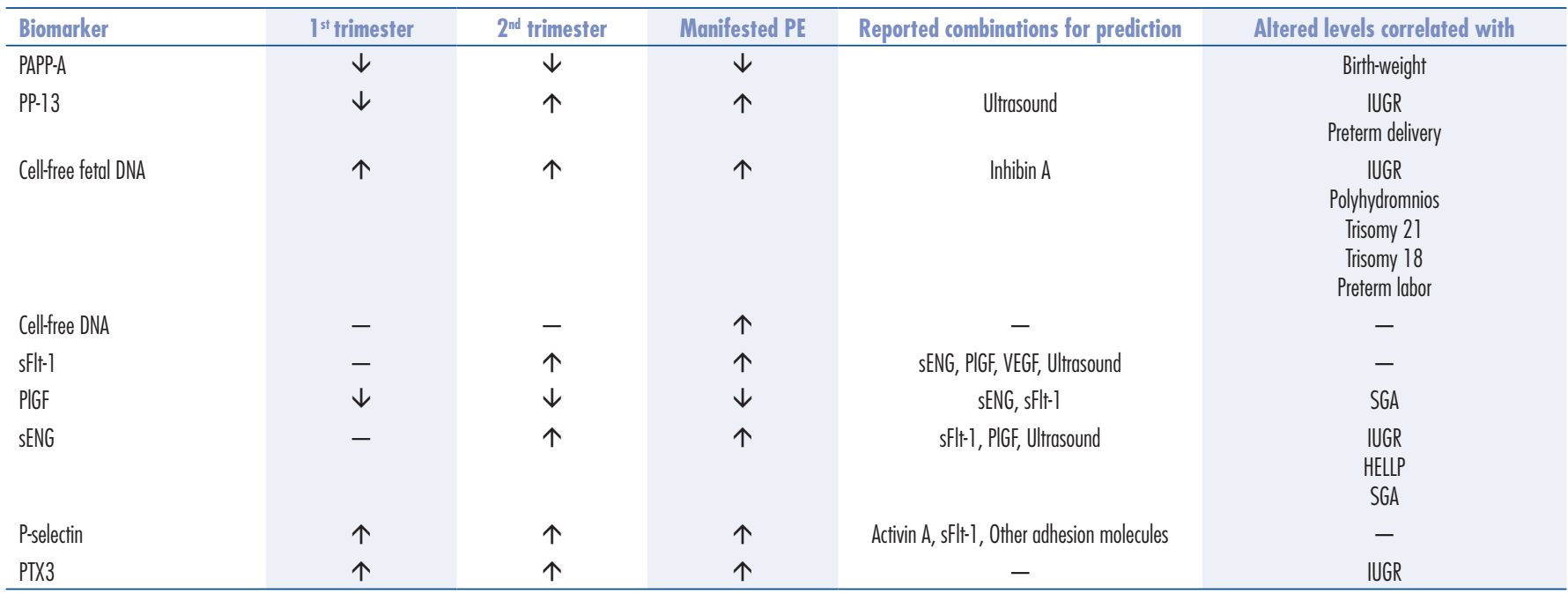

Table 2. First trimester multiparametric model detection rates for early-onset PE

\begin{tabular}{|c|c|c|c|c|c|c|}
\hline $\begin{array}{l}\text { DR at } 5 \% \\
\text { FPR }\end{array}$ & History & MAP & UA-PI & PAPP-A & PIGF & Reference \\
\hline 33 & $X$ & & & & & $\begin{array}{l}\text { Yu et al. }{ }^{66} \\
\text { Akolekar et al. } .^{67}\end{array}$ \\
\hline 38 & & & $X$ & & & Poon et al. ${ }^{36}$ \\
\hline 47 & $x$ & & & $X$ & & Akolekar et al. ${ }^{67}$ \\
\hline 54 & $x$ & & & & $x$ & Akolekar et al. ${ }^{67}$ \\
\hline 60 & $x$ & & $X$ & $X$ & & Foidart et al. ${ }^{68}$ \\
\hline 78 & $X$ & & $x$ & & $x$ & Foidart et al. ${ }^{68}$ \\
\hline 78 & $X$ & $X$ & $x$ & $x$ & $x$ & Akolekar et al. ${ }^{67}$ \\
\hline 84 & $X$ & $x$ & $x$ & $x$ & & Poon et al. ${ }^{69}$ \\
\hline 89 & $x$ & $x$ & $x$ & & $x$ & Poon et al. ${ }^{25}$ \\
\hline 93 & $x$ & $x$ & $x$ & $X$ & $x$ & Poon et al..$^{70}$ \\
\hline
\end{tabular}

History: body mass index, family history of PE, previous PE, ethnicity, smoking; MAP: mean arterial blood pressure; UA-PI: uterine artery pulsatility index.

many originating from the Fetal Medicine Foundation (FMF, London). Table $2^{66-70}$ summarizes the detection rate for multiple markers of $\mathrm{PE}$ in the first trimester.

One particularly promising predictive model for the first trimester has recently been published by Poon et al. ${ }^{70}$. The authors evaluated 7,797 women with singleton, first-trimester pregnancies attending clinics for routine care, with a $2 \%$ overall incidence of PE. The predictive model incorporated maternal factors, uterine artery Doppler, maternal MAP, PAPP-A, and PlGF. For a $5 \%$ false-positive rate, the sensitivity and specificity for early-onset PE were 93 and $94 \%$, respectively. The likelihood ratio for a positive test was 16.5 and the negative was 0.06 , easily meeting the World Health Organization (WHO) criteria for a screening test $^{21}$. As observed in other studies, the predictive results for late-onset $\mathrm{PE}$ and gestational hypertension were lower at 36 and $18 \%$, respectively. Overall, one in five women who screened as positive with the combined tests went on to develop a hypertensive disease of pregnancy. The editorial accompanying the article points out that these results need to be tested by other investigators and in different populations before we can be certain that this model for combined tests can be universally applied ${ }^{71}$. These results, however, are extremely promising, and the component tests of the model could, at least in the developed world, be easily measured in most settings ${ }^{21}$.

\section{Perspectives for prevention}

Many therapeutic interventions have been trialled, but the pattern of outcomes is similar. Initial small trials often show promising results followed by disappointing outcomes in larger studies ${ }^{21}$. Currently, no definitive treatment or effective prophylaxis for PE is in widespread clinical use. Delivery and consequent removal of the placenta is the "treatment", often with a premature baby as the result. Close surveillance of mother and fetus is necessary for the timing of delivery in order to reduce morbidity and mortality rates.

To date, only aspirin ${ }^{1}$ and calcium ${ }^{72}$ showed some benefits in terms of prevention. A recent meta-analysis of individualised patient data from 31 randomised trials involving 32,217 women, revealed that aspirin showed a significant $10 \%$ reduction in the incidence of $\mathrm{PE}$ (relative risk of $0.9,95 \% \mathrm{CI}=0.84-0.97)^{54}$. Similar reductions in delivery before 34 weeks $(\mathrm{RR}=0.90 ; 0.83-0.98)$ and a serious adverse outcome $(\mathrm{RR}=0.9 ; 0.85-0.96)$ were seen. The findings broadly supported those of the preceding Cochrane review ${ }^{21}$.

In 2009, Bujold et al. ${ }^{73}$ published a meta-analysis that assessed the influence of gestational age at the time 
of starting the aspirin treatment, on the incidence of $\mathrm{PE}$ in women at increased risk on the basis of abnormal uterine artery Doppler. They found a 52\% reduction in the risk of PE compared with the Control Group, when aspirin treatment was started before 16 weeks of pregnancy. When aspirin was started after 16 weeks, there was no significant reduction in PE risk.

The Cochrane review ${ }^{72}$ of trials found that calcium supplementation during pregnancy is a safe and relatively cost-effective means of reducing the risk of high blood pressure in women with increased risk, and women with low dietary calcium. No adverse effects were found, but further research is needed to find the ideal dosage for supplementation and to confirm the results that stem from several rather small trials. A large, multicenter trial performed between 1992 and 1995 (CPEP) ${ }^{74}$ did not find a risk reduction in healthy, nulliparous women. A more recent study ${ }^{75}$ showed that calcium supplementation did not prevent PE, but it reduced its severity and maternal and neonatal morbidity.

\section{Conclusion}

It is now increasingly accepted that PE is better defined as a syndrome rather than a single disorder. Earlyonset PE is strongly associated with deficient trophoblast invasion and failure of normal spiral artery remodeling. Late-onset PE may be caused by increased maternal vascular susceptibility to the normal inflammatory state of pregnancy or atherosis of a placenta that was initially normally developed. The most promising predictive models incorporate panels of tests evaluating different aspects of maternal susceptibility and placentation, such as maternal risk factors, mean arterial blood pressure, uterine artery Doppler, and biomarkers. There is sufficient data on some combinations of markers to make reasonable estimates of PE risk. Prospective studies are necessary to evaluate risk prediction in different populations. Furthermore, we need to evaluate the potential of novel biomarkers, generated by novel research strategies, in order to try to improve the predictive performance of the existing models.

\section{Referências}

1. Duley L, Henderson-Smart DJ, Knight M, King JF. Antiplatelet agents for preventing pre-eclampsia and its complications. Cochrane Database Syst Rev. 2004;(1):CD004659.

2. Thilaganathan B, Wormald B, Zanardini C, Sheldon J, Ralph E, Papageorghiou AT. Early-pregnancy multiple serum markers and second-trimester uterine artery Doppler in predicting preeclampsia. Obstet Gynecol. 2010;1 15(6):1233-8.

3. Report of the National High Blood Pressure Education Program Working Group on High Blood Pressure in Pregnancy. Am J Obstet Gynecol. 2000; 183(1):S1-22.

4. Redman CW, Sargent IL. Latest advances in understanding preeclampsia. Science. 2005;308(5728):1592-4.

5. Maynard SE, Min JY, Merchan J, Lim KH, Li J, Mondal S, et al. Excess placental soluble fms-like tyrosine kinase $1(\mathrm{sFlt} 1)$ may contribute to endothelial dysfunction, hypertension, and proteinuria in preeclampsia. J Clin Invest. 2003;1 11 (5):649-58.

6. Oliveira LG, Karumanchi A, Saas N. Pré-eclâmpsia: estresse oxidativo, inflamação e disfunção endotelial. Rev Bras Ginecol Obstet. 2010;32(12):609-16.

7. Harris LK, Keogh RJ, Wareing M, Baker PN, Cartwright JE, Aplin $J D$, et al. Invasive trophoblasts stimulate vascular smooth muscle cell apoptosis by a fas ligand-dependent mechanism. Am J Pathol. 2006; 169(5): 1863-74.

8. Keogh RJ, Harris LK, Freeman A, Baker PN, Aplin JD, Whitley GS, et al. Fetal-derived trophoblast use the apoptotic cytokine tumor necrosis factor-alpha-related apoptosis-inducing ligand to induce smooth muscle cell death. Circ Res. 2007;100(6):834-41.

9. Burton GJ, Woods AW, Jauniaux E, Kingdom JC. Rheological and physiological consequences of conversion of the maternal spiral arteries for uteroplacental blood flow during human pregnancy. Placenta. 2009;30(6):473-82.
10. Redman CW, Sacks GP, Sargent IL. Preeclampsia: an excessive maternal inflammatory response to pregnancy. Am J Obstet Gynecol. 1999; 180(2 Pt 1):499-506.

11. Murthi P, Doherty V, Said J, Donath S, Brennecke SP, Kalionis B. Homeobox gene HLXI expression is decreased in idiopathic human fetal growth restriction. Am J Pathol. 2006; 168(2):51 1-8.

12. Hall MH, Chng PK, MacGillivray I. Is routine antenatal care worth while? Lancet. 1980;2(8185):78-80.

13. Tucker JS, Hall MH, Howie PW, Reid ME, Barbour RS, Florey CD, et al. Should obstetricians see women with normal pregnancies? A multicentre randomized controlled trial of routine antenatal care by general practitioners and midwives compared with shared care led by obstetricians. BM. 1996;312(7030):554-9.

14. Askie LM, Duley L, Henderson-Smart DJ, Stewart LA; Paris Collaborative Group. Antiplatelet agents for prevention of preeclampsia: a meta-analysis of individual patient data. Lancet. 2007;369(9575):1791-8.

15. Staff AC. Circulating predictive biomarkers in preeclampsia. Pregnancy Hypertens. 2011;1(1):28-42.

16. Onwudiwe N, Yu CK, Poon LC, Spiliopoulos I, Nicolaides KH. Prediction of pre-eclampsia by a combination of maternal history, uterine artery Doppler and mean arterial pressure. Ultrasound Obstet Gynecol. 2008;32(7):877-83.

17. ACOG Committee on Practice Bulletins - Obstetrics. ACOG practice bulletin. Diagnosis and management of preeclampsia and eclampsia. Number 33, January 2002. Obstet Gynecol. 2002;99(1):159-67.

18. Poon LC, Kametas NA, Chelemen T, Leal A, Nicolaides KH. Maternal risk factors for hypertensive disorders in pregnancy: a multivariate approach. J Hum Hypertens. 2010;24(2):104-10. 
19. Cetin I, Huppertz B, Burton G, Cuckle H, Gonen R, Lapaire O, et al. Pregenesys pre-eclampsia markers consensus meeting: What do we require from markers, risk assessment and model systems to tailor preventive strategies? Placenta. 2011;32 Suppl:S4-16.

20. North RA, McCowan LM, Dekker GA, Poston L, Chan EH, Stewart AW, et al. Clinical risk prediction for pre-eclampsia in nulliparous women: development of model in international prospective cohort. BM. $2011 ; 342: \mathrm{d} 1875$.

21. Leslie K, Thilaganathan B, Papageorghiou A. Early prediction and prevention of pre-eclampsia. Best Pract Res Clin Obstet Gynaecol. $2011 ; 25(3): 343-54$.

22. Cnossen JS, Vollebregt KC, de Vrieze N, ter Riet G, Mol BW, Franx $A$, et al. Accuracy of mean arterial pressure and blood pressure measurements in predicting pre-eclampsia: systematic review and meta-analysis. BM. 2008;336(7653):1117-20.

23. Poon LC, Staboulidou I, Maiz N, Plasencia W, Nicolaides KH. Hypertensive disorders in pregnancy: screening by uterine artery Doppler at 11-13 weeks. Ultrasound Obstet Gynecol. 2009;34(2): 142-8.

24. Huppertz B, Abe E, Murthi P, Nagamatsu T, Szukiewicz D, Salafia C. Placental angiogenesis, maternal and fetal vessels-a workshop report. Placenta. 2007;28 Suppl A:S94-6.

25. Poon LC, Akolekar R, Lachmann R, Beta J, Nicolaides KH. Hypertensive disorders in pregnancy: screening by biophysical and biochemical markers at 11-13 weeks. Ultrasound Obstet Gynecol. 2010;35(6):662-70.

26. Martin AM, Bindra R, Curcio P, Cicero S, Nicolaides KH. Screening for pre-eclampsia and fetal growth restriction by uterine artery Doppler at 1 1-14 weeks of gestation. Ultrasound Obstet Gynecol. 2001; 18(6):583-6.

27. Scazzocchio E, Figueras F. Contemporary prediction of preeclampsia. Curr Opin Obstet Gynecol. 2011 ; 23(2):65-71.

28. Spencer K, Cowans NJ, Chefetz I, Tal J, Meiri H. First-trimester maternal serum PP-13, PAPP-A and second-trimester uterine artery Doppler pulsatility index as markers of pre-eclampsia. Ultrasound Obstet Gynecol. 2007;29(2): 128-34.

29. Costa FS, Cunha SP, Berezowsky AT. Doplervelocimetria das artérias uterinas na predição de complicações em gestações de baixo risco. Rev Bras Ginecol Obstet. 2005;27(6):323-30.

30. Cuckle HS. Screening for pre-eclampsia: lessons from aneuploidy screening. Placenta. 2011;32 Suppl:S42-8.

31 . Harrington K. Early screening for pre-eclampsia and intrauterine growth restriction. Ultrasound Obstet Gynecol. 201 1;37(5):623-4.

32. Hata T, Tanaka H, Noguchi J, Hata K. Three-dimensional ultrasound evaluation of the placenta. Placenta. $2011 ; 32(2): 105-15$.

33. Odibo AO, Goetzinger KR, Huster KM, Christiansen JK, Odibo L, Tuuli MG. Placental volume and vascular flow assessed by 3D power Doppler and adverse pregnancy outcomes. Placenta. $2011 ; 32(3): 230-4$.

34. Dar P, Gebb J, Reimers L, Bernstein PS, Chazotte C, Merkatz IR. First-trimester 3-dimensional power Doppler of the uteroplacental circulation space: a potential screening method for preeclampsia. Am J Obstet Gynecol. 2010;203(3):238.e 1-7.

35. Giguère $Y$, Charland M, Bujold E, Bernard N, Grenier S, Rousseau $F$, et al. Combining biochemical and ultrasonographic markers in predicting preeclampsia: a systematic review. Clin Chem. 2010;56(3):361-75.

36. Poon LC, Maiz N, Valencia C, Plasencia W, Nicolaides KH. First-trimester maternal serum pregnancy-associated plasma protein-A and pre-eclampsia. Ultrasound Obstet Gynecol. 2009; 33(1):23-33
37. Bohn $\mathrm{H}$, Kraus W, Winckler W. Purification and characterization of two new soluble placental tissue proteins (PP13 and PP17). Oncodev Biol Med. 1983;4(5):343-50.

38. Huppertz B, Sammar M, Chefetz I, Neumaier-Wagner P, Bartz $\mathrm{C}$, Meiri $\mathrm{H}$. Longitudinal determination of serum placental protein 13 during development of preeclampsia. Fetal Diagn Ther. $2008 ; 24(3): 230-6$.

39. Than NG, Romero R, Goodman M, Weckle A, Xing J, Dong Z, ef al. A primate subfamily of galectins expressed at the maternal-fetal interface that promote immune cell death. Proc Natl Acad Sci U S A. $2009 ; 106(24): 9731-6$.

40. Khalil A, Cowans NJ, Spencer K, Goichman S, Meiri H, Harrington K. First trimester maternal serum placental protein 13 for the prediction of pre-eclampsia in women with a priori high risk. Prenat Diagn. 2009;29(8):781-9.

41. Sekizawa A, Purwosunu Y, Yoshimura S, Nakamura M, Shimizu $\mathrm{H}$, Okai T, et al. PP13 mRNA expression in trophoblasts from preeclamptic placentas. Reprod Sci. 2009;16(4):408-13.

42. Grill S, Rusterholz C, Zanetti-Dallenbach R, Tercanli S, Holzgreve W, Hahn S, et al. Potential markers of preeclampsia-a review. Reprod Biol Endocrinol. 2009;7:70.

43. Kristensen K, Larsson I, Hansson SR. Increased cystatin C expression in the pre-eclamptic placenta. Mol Hum Reprod. 2007; 13(3): 189-95.

44. Kristensen K, Wide-Swensson D, Schmidt C, Blirup-Jensen S, Lindstrom V, Strevens $H$, et al. Cystatin C, beta-2-microglobulin and beta-trace protein in pre-eclampsia. Acta Obstet Gynecol Scand. 2007;86(8):921-6.

45. Thilaganathan B, Ralph E, Papageorghiou AT, Melchiorre K, Sheldon J. Raised maternal serum cystatin C: an early pregnancy marker for preeclampsia. Reprod Sci. 2009;16(8):788-93.

46. Hahn S, Holzgreve W. Fetal cells and cell-free fetal DNA in maternal blood: new insights into pre-eclampsia. Hum Reprod Update. 2002;8(6):501-8.

47. Bianchi DW, Williams JM, Sullivan LM, Hanson FW, Klinger $\mathrm{KW}$, Shuber AP. PCR quantitation of fetal cells in maternal blood in normal and aneuploid pregnancies. Am J Hum Genet. 1997;61(4):822-9.

48. Alberry MS, Maddocks DG, Hadi MA, Metawi H, Hunt LP, AbdelFattah SA, et al. Quantification of cell free fetal DNA in maternal plasma in normal pregnancies and in pregnancies with placental dysfunction. Am J Obstet Gynecol. 2009;200(1):98.e 1-6.

49. Levine RJ, Qian C, Leshane ES, Yu KF, England L, Schisterman EF, et al. Two-stage elevation of cell-free fetal DNA in maternal sera before onset of preeclampsia. Am J Obstet Gynecol. 2004;190(3):707-13.

50. Gupta AK, Holzgreve W, Huppertz B, Malek A, Schneider H, Hahn S. Detection of fetal DNA and RNA in placenta-derived syncytiotrophoblast microparticles generated in vitro. Clin Chem. 2004;50(1 1):2187-90.

51. Zhong XY, Gebhardt S, Hillermann R, Tofa KC, Holzgreve W, Hahn $S$. Parallel assessment of circulatory fetal DNA and corticotropinreleasing hormone mRNA in early- and late-onset preeclampsia. Clin Chem. 2005;51(9):1730-3.

52. Purwosunu $Y$, Sekizawa A, Farina A, Wibowo N, Okazaki S, Nakamura $M$, et al. Cell-free mRNA concentrations of $C R H$, PLAC1, and selectin-P are increased in the plasma of pregnant women with preeclampsia. Prenat Diagn. 2007;27(8):772-7.

53. Petraglia F, Vaughan J, Vale W. Inhibin and activin modulate the release of gonadotropin-releasing hormone, human chorionic gonadotropin, and progesterone from cultured human placental cells. Proc Natl Acad Sci U S A. 1989;86(13):5114-7. 
54. Muttukrishna S, North RA, Morris J, Schellenberg JC, Taylor RS, Asselin J, et al. Serum inhibin A and activin A are elevated prior to the onset of pre-eclampsia. Hum Reprod. 2000; 15(7): 1640-5.

55. Sibai BM, Koch MA, Freire S, Pinto e Silva JL, Rudge MV, Martins-Costa $S$, et al. Serum inhibin A and angiogenic factor levels in pregnancies with previous preeclampsia and/or chronic hypertension: are they useful markers for prediction of subsequent preeclampsia? Am J Obstet Gynecol. 2008; 199(3):268.el-9.

56. Verlohren S, Galindo A, Schlembach D, Zeisler H, Herraiz I, Moertl MG, et al. An automated method for the determination of the sFlt-1/PIGF ratio in the assessment of preeclampsia. Am J Obstet Gynecol. 2010;202(2):161.

57. Levine RJ, Maynard SE, Qian C, Lim KH, England L, Yu KF, et al. Circulating angiogenic factors and the risk of preeclampsia. $\mathrm{N}$ Engl J Med. 2004;350(7):672-83.

58. Clark DE, Smith SK, Licence D, Evans AL, Charnock-Jones DS Comparison of expression patterns for placenta growth factor, vascular endothelial growth factor (VEGF), VEGF-B and VEGF-C in the human placenta throughout gestation. J Endocrinol. 1998; $159(3): 459-67$.

59. Akolekar R, Zaragoza E, Poon LC, Pepes S, Nicolaides KH. Maternal serum placental growth factor at $11+0$ to $13+6$ weeks of gestation in the prediction of pre-eclampsia. Ultrasound Obstet Gynecol. 2008;32(6):732-9.

60. Robinson CJ, Johnson DD, Chang EY, Armstrong DM, Wang W. Evaluation of placenta growth factor and soluble Fms-like tyrosine kinase 1 receptor levels in mild and severe preeclampsia. Am J Obstet Gynecol. 2006; 195(1):255-9.

61. Wikstrom AK, Larsson A, Eriksson UJ, Nash P, Nordén-Lindeberg $S$, Olovsson M. Placental growth factor and soluble FMS-like tyrosine kinase-1 in early-onset and late-onset preeclampsia. Obstet Gynecol. 2007;109(6):1368-74.

62. Stepan H, Kramer T, Faber R. Maternal plasma concentrations of soluble endoglin in pregnancies with intrauterine growth restriction. J Clin Endocrinol Metab. 2007;92(7):2831-4.

63. Cetin I, Cozzi V, Pasqualini F, Nebuloni M, Garlanda C, Vago $\mathrm{L}$, et al. Elevated maternal levels of the long pentraxin 3 (PTX3) in preeclampsia and intrauterine growth restriction. Am J Obstet Gynecol. 2006; 194(5):1347-53.

64. Akolekar R, Casagrandi D, Livanos P, Tetteh A, Nicolaides KH. Maternal plasma pentraxin 3 at 11 to 13 weeks of gestation in hypertensive disorders of pregnancy. Prenat Diagn. 2009;29(10):934-8.
65. Cetin I, Cozzi V, Papageorghiou AT, Maina V, Montanelli A, Garlanda C, et al. First trimester PTX3 levels in women who subsequently develop preeclampsia and fetal growth restriction. Acta Obstet Gynecol Scand. 2009;88(7):846-9.

66. Yu CK, Smith GC, Papageorghiou AT, Cacho AM, Nicolaides KH; Fetal Medicine Foundation Second Trimester Screening Group. An integrated model for the prediction of preeclampsia using maternal factors and uterine artery Doppler velocimetry in unselected lowrisk women. Am J Obstet Gynecol. 2005; 193(2):429-36.

67. Akolekar R, Syngelaki A, Sarquis R, Zvanca M, Nicolaides KH. Prediction of early, intermediate and late pre-eclampsia from maternal factors, biophysical and biochemical markers at 11-13 weeks. Prenat Diagn. $2011 ; 31(1): 66-74$.

68. Foidart JM, Munaut C, Chantraine F, Akolekar R, Nicolaides KH. Maternal plasma soluble endoglin at 11-13 weeks' gestation in pre-eclampsia. Ultrasound Obstet Gynecol. 2010;35(6):680-7.

69. Poon LC, Stratieva V, Piras S, Piri S, Nicolaides KH. Hypertensive disorders in pregnancy: combined screening by uterine artery Doppler, blood pressure and serum PAPP-A at 11-13 weeks. Prenat Diagn. 2010;30(3):216-23.

70. Poon LC, Kametas NA, Maiz N, Akolekar R, Nicolaides KH. First-trimester prediction of hypertensive disorders in pregnancy. Hypertension. 2009;53(5):812-8.

71. Levine RJ, Lindheimer MD. First-trimester prediction of early preeclampsia: a possibility at last! Hypertension. 2009;53(5):747-8.

72. Hofmeyr GJ, Lawrie TA, Atallah AN, Duley L. Calcium supplementation during pregnancy for preventing hypertensive disorders and related problems. Cochrane Database Syst Rev. 2010; (8):CD001059.

73. Bujold E, Morency AM, Roberge S, Lacasse Y, Forest JC, Giguère Y. Acetylsalicylic acid for the prevention of preeclampsia and intra-uterine growth restriction in women with abnormal uterine artery Doppler: a systematic review and meta-analysis. J Obstet Gynaecol Can. 2009;31(9):818-26.

74. Levine RJ, Esterlitz JR, Raymond EG, DerSimonian R, Hauth JC, Ben Curet $L$, et al. Trial of Calcium for Preeclampsia Prevention (CPEP): rationale, design, and methods. Control Clin Trials. 1996; 17(5):442-69.

75. Villar J, Abdel-Aleem H, Merialdi M, Mathai M, Ali MM, Zavaleta $N$, et al. World Health Organization randomized trial of calcium supplementation among low calcium intake pregnant women. Am J Obstet Gynecol. 2006;194(3):639-49. 